\title{
Political Communication Network of Women of Dynasty
}

\author{
$1^{\text {st* }}$ Sa'diyah El Adawiyah \\ Dept. of Communication Science \\ Universitas Muhammadivah Jakarta \\ Jakarta, Indonesia \\ sadiyah.eladawiyah@umj.ac.id
}

\author{
$2^{\text {nd }}$ Imsar Gunawan \\ Dept. of Communication Science \\ Universitas Al Azhar Indonesia \\ Jakarta, Indonesia \\ imsar.gunawan@uai.ac.id
}

\author{
$3^{\text {rd }}$ Tria Patrianti \\ Dept. of Communication Science \\ Universitas Muhammadiyah Jakarta \\ Jakarta, Indonesia \\ tria.padmadisastra@gmail.com
}

\begin{abstract}
Women's involvement in politics have led them to become political actors with good communication as mandatory. Political communication represents the interests of groups. The women of dynasty's political communication network in achieving leadership enables them to map and read the needs and problems faced by the community. Through this political network, the role of political campaign team, volunteers, and parties in winning the 2015 election campaign become visible. This study aims to show and see the relationship between actors in political network. Using complete network analysis, this research uses actor (node) as its unit analysis. Every actor in the network has different involvement respectively.
\end{abstract}

Keywords-Dynasty, Political Communication, Political Communication Network, Leadership

\section{INTRODUCTION}

The presence of women as regional leader is one of the emerging gender-just policy strategies. Nugroho in Gender and Gender Mainstreaming Strategies in Indonesia, shows that countries with significant number of women with policy formulation as in parliament produce policies on progressive women such as what happens in Sweden, Finland, Denmark, Norway, Germany, and the Netherlands. In line with that, leadership of women in various regions in Indonesia then appear [1].

Failure to communicate often results in misunderstandings, losses and even havoc. The risk is not only on individual level, but in institutions, communities, and even countries level respectively [2]. Politicians communicate as representatives of a group and the messages of politicians are to propose and/or to protect the aim of political interests. Political communication represents the interests of groups. Thus, politicians seek influence through communication [3].

The women of dynasty's political communication network in achieving leadership enables them to map and read the needs and problems faced by the community. Through this political network, the role of political campaign team, volunteers, and parties in winning the 2015 election campaign is visible.

\section{LITERATURE REVIEWS}

\section{A. Political Communication}

Lord Windlesham in the book titled What is Political Communication states that "Political Communication is the deliberate passing of a political message by a sender to a receiver with the intention of making the receiver behave in a way that might not otherwise have done" (Michael Tracey 1997:4).

Formulates political communication as a political outcome from the social class. Whereas Galdnoor states that political communication is a political infrastructure, which is a combination of various social interactions where informations relating to joint ventures and power relations enter into circulation [4]. Political communication is therefore the process of diverting messages, an intention or meaning, from the sender to the receiver which involves the process of putting meaning toward power, authority, public life, government, state, conflict and its resolution, policy, decision making, distribution and allocation [5].

Richard R. Fagen in his Political and communication book (1996), illustrates the relevance of political science and communication as a field of study. This can be seen through the analysis presented, in discussing the communicated political events. References used in viewing politics and communication are from Harold D. Lasswell framework (1948); Who says What, in Which Channel, To Whom, and With What Effect [6].

\section{B. Women in Regional Leadership}

Leaders are agents of change, whose behavior will affect others more than the behavior of others affect them. Leadership arises when one group member changes the motivation or competition of other members in the group.

Leadership as "a process of influencing others to understand and agree about what needs to be done and how to do it, and the process of facilitating individual and collective efforts to accomplish shared objectives

\section{RESEARCH METHODS}

The research uses complete network analysis level with node as its unit analysis. This study aims to describe and see how the relationship between actors in a network that focuses on all actors in the network. In a network analysis study, the important question is which actors (nodes) stand out or are the most decisive in the network. Which actor determines or 
stands out is called centrality. Centrality is a person who has a prominent position or power in the network, see about the position of the actor (node) in the whole network and see how central the actor is in the network. This study will discuss and analyze the measurement of centrality which includes degree of centrality, closeness of centrality and betweeness centrality. According to Eriyanto, when describing the position of actors in the network whose position is in the degree of centrality, closeness centrality and betweeness centrality, its centrality values change if the population is also different. This research takes a fast water pool agribusiness effort to analyze its communication network [8].

\section{RESULT AND DISCUSSION}

Communication formed in a social environment is an activity that aims to send and receive messages to provide changes to individuals. Communication is often interpreted as an activity carried out to share information. [9].

Communication network is a description of "how say to whom" (who talks to whom) in a group or social system. Communication networks can describe interpersonal communication that opinionated leaders and followers will form communication relationships with one another on one topic, which occurs in a particular social system such as a village, an organization, or a company. Researcher seeks the degree of centrality, the level of togetherness (Beetweness) and the level of closeness of each node.

The communication network illustrates the pattern of interaction that exists between individuals in the group. The process of forming a communication network in the political struggle for women in the electoral area occurs from the result of interaction conducted by successful teams, volunteer, and their links with the aim of meeting the information it needs to win and attract the attention of its constituents. The pattern of interaction between prospective regional leaders and the political campaign staff shows their communication behavior in giving and receiving and disseminating information. The analysis of the communication network will give an overview of who's involved in the delivery of information, how information distribution goes to each node (actor) and how the existing communication network is formed [9].

The communication network is carried out towards the actors involved in the process of women's political campaigns to the regions. The actors helped women regional leader in fighting over their constituents. The actors consisted of candidates for regional leader consultants, supporting political parties, political campaign staff, community mobilizers, journalists, and volunteer with a total of 14 people. Before conducting a sociogram analysis, all individuals in the network are given a numeric code ranging from 1 to 14. The coding can be seen in Table 1 below:

TABLE I. DISTRIBUTION OF NODE CODES (ACTORS) ON BUREAUCRATIC POLITICAL COMMUNICATION

\begin{tabular}{|l|l|l|l|}
\hline No. & \multicolumn{1}{|c|}{ The Role of Node } & \multicolumn{1}{|c|}{$\begin{array}{c}\text { Amount of } \\
\text { Node }\end{array}$} & \multicolumn{1}{c|}{$\begin{array}{c}\text { Code of } \\
\text { Node }\end{array}$} \\
\hline 1. & $\begin{array}{l}\text { Candidates for Head \& Deputy } \\
\text { Head of Region }\end{array}$ & 1 & 1 \\
\hline 2. & Political Campaign Stff & 1 & 2 \\
\hline 3. & Consultant & 2 & 3,6 \\
\hline
\end{tabular}

\begin{tabular}{|l|l|l|l|}
\hline 4. & Businessman & 1 & 7 \\
\hline 5. & Community & 2 & 4,5 \\
\hline 6. & Volunteer & 1 & 8 \\
\hline Total & 8 & \\
\hline
\end{tabular}

The sociogram in Figure 1 illustrates the pattern of interactions that occur between the nodes (actors) in prospective regional leaders, consultants, supporting political parties, political campaign staff, community mobilizers, journalists, and sympathizers. Based on the figure below, the structure of the network formed is centered because there are individuals who are at the center of the network. The centralized network structure is called a wheel structure [10]. This is also consistent with the results of research Sulistiawati, Lubis, \& Mulyani which says that this wheelshaped network structure is a very centralized pattern, superior to routine tasks that can receive a number of errors [11].

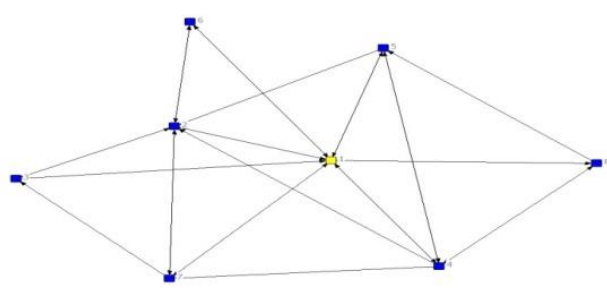

Fig. 1. Sociogram Analysis of Bureaucratic Political Communication Networks

In the sociogram of political communication networks for bureaucratic segment, the actors have a special role in the network. Referring to Rogers \& Kincaid and Gunawan et al.,[9] , one of the functions of communication network analysis is to identify individuals who have special role in the network. In line with that, a number of specific roles held by actors in the political communication network of women regional leaders are:

\section{A. Opinion Leader}

Based on Figure 1 above and the results of the UCINET 6 measurement that will be discussed later (Table 2 and Table 3), it can be identified that individuals with the strongest ties are the ones in node one. These individuals are regional female leader with strong network as connected with various other nodes. This is due to the candidate's connectedness with political campaign staff, consultant, volunteer, political figures, communities and their constituents.

\section{B. The Most Well-Known Network (Star)}

As found in opinion leaders, stars are also identified through the number of individual ties in the network. Stars are identified as individuals who have the most frequent communication intensity. In this connection, the political communication network in the bureaucratic segment that becomes the star is in node 2 . This individual is a political cadre and consultant with high experience and connections in his constituency. Actors involved in the politics of women regional leader must go through this star actor for information, usually for seeking and contacting these two nodes. 


\section{Degree of Centrality}

Degree Centrality shows the popularity of actors in communication networks. Degree is the number of links to and from the actor. This research has directed in its network, this degree can be indegree and outdegree. The higher the centrality value, the better the node will be. The maximum number of degrees centrality for the actor is $\mathrm{N}-1$ or the number of node populations is reduced by one. Outdegree centrality is the link or relationship given by one actor to other actors in the network. This is used to measure the expansion / expansion of an actor. An actor who has the highest outdegree centrality value means having a wide communication network with the community. Based on measurements using UCINET 6 (Table 2), the results obtained measure outdegree centrality between 0.171 to 0.543 . That is, the value of outdegree centrality or high connectedness of the political communication network of women regional heads is 54.3 percent, while the lowest is at 17.1 percent. These results indicate that the connectedness of each of the actors is very high.

TABLE II. DISTRIBUTION OF DEGREES OF CENTRALITY IN INTERPERSONAL COMMUNICATION NETWORKS BASED ON NORMALIZED VALUES

\begin{tabular}{|l|l|l|l|}
\hline $\begin{array}{c}\text { The degree of } \\
\text { centrality }\end{array}$ & \multicolumn{1}{|c|}{ Actor } & Score & \multicolumn{1}{c|}{ Role } \\
\hline $\begin{array}{l}\text { Outdegree } \\
\text { centrality }\end{array}$ & Actor number 1 & 0.543 & $\begin{array}{l}\text { Female Regional } \\
\text { Leader Candidate }\end{array}$ \\
\cline { 2 - 4 } & Actor number 2 & 0.314 & $\begin{array}{l}\text { Political Campaign } \\
\text { Staff }\end{array}$ \\
\cline { 2 - 5 } & Actor number 4 & 0.314 & Community \\
\cline { 2 - 5 } & Actor number 5 & 0.257 & Community \\
\hline \multirow{3}{*}{$\begin{array}{l}\text { Indegree } \\
\text { centrality }\end{array}$} & Actor number 1 & 0.886 & $\begin{array}{l}\text { Female Regional } \\
\text { Leader Candidate }\end{array}$ \\
\cline { 2 - 5 } & Actor number 2 & 0.400 & $\begin{array}{l}\text { Political Campaign } \\
\text { Staff }\end{array}$ \\
\cline { 2 - 5 } & Actor number 3 & 0.257 & Community \\
\cline { 2 - 4 } & Actor number 4 & 0.200 & Community \\
\hline
\end{tabular}

Based on the UCINET 6 measurement, the results above show or identify that the actors who have the highest outdegree centrality value are actors number 1 (value 0.543 ), 2 (value 0.314 ), 4 (value 0.314), and 5 (value 0.257). Actor number 1 is a female regional leader candidate who is able to access all actors involved in winning female regional leader candidates. This actor uses information obtained from various parties to get closer to his supporters and constituents. The actor with number 2 is the success team of women candidates for regional head. The Actor provides strategies and input to women regional heads to behave and schedule campaigns and other activities that support the winning candidate's strategy. Whereas actors number 4 and 5 are community leaders who support women candidates for regional heads. They become the engine and information search engine to get various kinds of information needed by prospective regional leader to get closer to their supporters and constituents.

Apart from seeing outdegree centrality, this study sees the indegree centrality, a number of personal ties that a person receives from other actors and generally to measure the prestige or popularity of an actor. Based on the results of measurements with UCINET 6, the value of indegree centrality is between 0.057 to 0.886 . In addition, the identification of the results of the largest indegree centrality (Table 2) is actor number 1 (value 0.886), actor number 2 (value 0.400), actor number 3 (value 0.257) and actor number 4 (value 0.200). Same is the case with outdegree centrality, actor number 1 is a leader and deputy candidate of the region. This actor uses information obtained from various parties to get closer to his supporters and constituents. The result of indegree centrality shows that the role of actor 1 is very high in contributing to the understanding of constituents towards themselves.

The findings regarding the centrality of individuals in the network as described above, are in line with what was stated by (Jahi, 1988) which states that individuals who act as leaders or opinion leaders have a number of attributes that distinguish them from people or other group members. Accordingly, it is known that actors who have a high degree of centrality (at the center of the network) have credibility and integrity relating to the dissemination of information regarding the political role of women regional heads.

\section{Closeness Centrality}

Closeness centrality shows how close the actor (node) is to all the other actors in a network. Proximity is measured by how many steps (path) an actor can contact and be contacted by other actors in the network. Closeness centrality is the opposite of degree centrality. In closeness centrality, the smaller the value, the better. A small value shows the proximity of the node (actor) to other nodes in the network. Closeness centrality measures the degree of independence of an actor. Actors who have high closeness centrality value, are able to reach other actors without intermediaries, or can reach everyone in the network and be visible as a person who is mobile in the network. Based on the results of the calculation of UCINET 6, the value of closeness centrality is between 0.583 to 1,000 . This value indicates the value of closeness of each actor is in the very high category because the proximity value is at 100 percent. Based on the results of these measurements, the actor with the highest closeness centrality value (Table 3 ) can be identified as actors number $1,4,2$ and 5 .

TABLE III. SPREAD ClOSENESS CENTRALITY BASED ON NORMALIZED VALUE

\begin{tabular}{|c|l|l|l|}
\hline $\begin{array}{c}\text { Type of } \\
\text { Centrality }\end{array}$ & Actor & Score & \multicolumn{1}{|c|}{ Role } \\
\hline \multirow{4}{*}{$\begin{array}{l}\text { Closeness } \\
\text { Centrality }\end{array}$} & Actor number 1 & 1.000 & $\begin{array}{l}\text { Female Regional } \\
\text { Leader Candidate }\end{array}$ \\
\cline { 2 - 4 } & Actor number 4 & 0.765 & Community \\
\cline { 2 - 4 } & Actor number 2 & 0.722 & $\begin{array}{l}\text { Political Campaign } \\
\text { Staff }\end{array}$ \\
\cline { 2 - 4 } & Actor number 5 & 0.684 & Community \\
\hline
\end{tabular}

Actor 1 is known personally active in a variety of social activities with various programs that have been implemented both in the fields of education, health, environment and youth. Activities that are always followed by Actor 1 among other are Community Reading Park or Taman Bacaan Masyarakat (TBM) or Community of Reading Favors (MAGMA), go green, and gratuitous fogging initiated by Actor 1 (Lutfi, 2017; 59). Political communicators are the dominant element in the process of effective communication, how to arrange and deliver messages to the public (constituents). A person's figure is very influential in gaining or maintaining power both 
physically, personality and track record of family background, life history, education, achievements. There are 4 capital owned by Actor 1 as a political communicator, namely: Personal Capital. Social Capital, Material Capital and Political Capital.

\section{E. Personal capital (attractiveness)}

Actor 1 is a "complete package" (Dewi, 2017; 50) for dynastic families (family ties). Actor 1 is beautiful with a myriad of glorious achievements as Mojang Bandung, from a local beauty pageant in 1995. In 1996 she was chosen as the Tourism Ambassador and Favorite winner in the Indonesia Beauty Pageant. Actor 1 is not only beautiful but gaining master degree in Law. Actor 1 has better education and it is added value for personal capital that everyone wish for overcoming problems and thinking systematically in solving every problem

\section{F. Social Capital (equality / empathy)}

Since the 2008, Actor 1 has often visited study groups in the Pakuhaji area. Listening to the complaints of mothers starting from the problems of education, health and various other social problems. continued until the 2010 and 2015. Local Election. Various social activities were carried out by Actor 1, starting from being actively involved in Indonesian's Red Cross, community social groups, recitals, family movers. In the period of 2010-2015 Actor 1 activities grew significantly as being active in family gatherings (PKK), social activists and humanity of the National Renewal Forum (FPK), a community-based movement initiated by Actor 1 to win first place at the National level of Independent and sustainable Community Reading Park A lot of social capital is done by Actor 1 to capture and be close to the community. Especially the relationship with actor 4 is involved in every TBM activity held in various areas of its leadership. Actor 4 is the founder of TBM as well as a successful entrepreneur who is active in social activities and likes to read as a literacy for the local community in the area of actor 1. The support of actor 1 in developing TBM is welcomed by actor 4. Every opportunity to open a new TBM conducted by actor 4 is always attended Actor 1 . While Actor 5 is the driving force of one of the existing TBMs.

\section{G. Political Capital (power)}

The emergence of Actor 1 in politics at the instigation of her husband as a businessman in a Dynasty family. Actor 1 has been increasingly known to the public since its defeat in the 2008 elections. Actor 1 began to re-sharpen himself and study and continue to learn in politics with actor 2 (political consultants). However, it is undeniable the "kinship politics" analysis of Abdul Hamid $(2014 ; 579)$ as one of the factors in Actor's political capital 1. Political capital owned by Actor 1 as an incumbent candidate for the 2015 elections is not owned by other candidates. The status as an incumbent is used by Actor 1 and actor 2 of his success team to conduct political outreach, for example Actor 1 visits recitals, to social groups by providing assistance tailored to needs deemed important.

\section{H. Material Capital}

The message is what Actor 1 delivered through the collaboration of actor 2 and actor 4 through the work program. The purpose of forming messages in political campaigns is to influence voters and get the support needed to win the election.

\section{CONCLUSION}

The dynastic women's political network involves actors with a fairly high degree of centrality (at the center of the network) with credibility and integrity related to the dissemination of information about the political role of women regional heads.

\section{ACKNOWLEDGMENT}

B. G. Thanks for FISIP University of Muhammadiyah Jakarta, APIK PTM, Aspikom, Jogjakarta Communication COnference" and Dept. of Communication Science, Faculty of Social and Political Science, University of Al Azhar Indonesia.

\section{REFERENCES}

[1] R. Nugroho, Gender dan Strategi : pengarus-utamanya di Indonesia. Yogyakarta: Pustaka Pelajar, 2008.

[2] D. Mulyana, Komunikasi Efektif: Suatu Pendekatan Lintas budaya. Bandung: PT Remaja Rosdakarya, 2004.

[3] L. Arrianie, Komunikasi politik: politisi dan pencitraan di panggung politik. Bandung: Widya Padjadjaran, 2010.

[4] M. Zamroni, "Perempuan dalam kajian komunikasi politik dan gender," vol. XIV, no. 1, pp. 103-132, 2013.

[5] Damsar, Pengantar Sosiologi Politik. Jakarta: Prenandamedia Group, 2010.

[6] A. V. Hubeis, Pemberdayaan Perempuan Dari Masa Ke Masa. Bogor: IPB Press, 2016.

[7] G. Yuki, Leadership in Organizations, 7th Editio. New York: State University of New York, Albany, 2010.

[8] Eriyanto, Analisis Jaringan Komunikasi. Jakarta: Prenandamedia Group, 2014.

[9] I. Gunawan, N. Purnaningsih, and B. G. Sugihen, "Jaringan Komunikasi Pelaku Inovasi Agribisnis Kolam Ikan Air Deras Di Kecamatan Caringin Kabupaten Bogor," J. KMP (Jurnal Komun. Pembangunan), vol. 15, no. 2, pp. 56-68, 2017.

[10] J. A. DeVito, Komunikasi Antar Manusia. Jakarta: Professional Books, 1997.

[11] A. Sulistiawati, D. P. Lubis, and E. S. Mulyani, "Analisis Jaringan Sosial Dalam Gabungan Kelompok Tani (Gapoktan) Tani Berkah," Sodality J. Sosiol. Pedesaan, vol. 2, no. 2, pp. 76-82, 2014 